\title{
Plurihormonality and Pluripotentiality of GH-Secreting Adenoma Based on Pathological Analysis of 242 patients with Acromegaly
}

\section{Hidetoshi lkeda*}

Research Institute for Pituitary Diseases, Southern Tohoku General Hospital, Koriyama, Fukushima 963-8563, Japan

\begin{abstract}
Aim: To disclose the nature of plurihormonality and pluripotentiality of growth hormone $(\mathrm{GH})$-secreting adenomas.

Methods: A total of 242 patients with $\mathrm{GH}$-secreting adenomas were studied by immunohistochemistry, electron microscopy and clonal analysis (X-linked human androgen receptor gene assay).

Results: GH-secreting adenoma showed a greater variety and number of hormones produced compared with those of PRL-secreting adenomas ( $p<0.01$, Welch's $t$-test).

The number of cases with $\mathrm{GH}$-secreting adenoma that simultaneously produced ACTH were $50(21 \%)$ out of 242. There were two different types of co-localization of ACTH- and GH-secreting cells within adenoma; (1) adenoma with co-localized ACTH- and $\mathrm{GH}$-immunoreactive cells in a random pattern, and (2) adenoma with a small cell cluster of ACTH-immunoreactive cells within $\mathrm{GH}$-secreting adenomas. There were three different tissue phenotypes in GH-secreting adenomas; (a) mixed tumors composed of adenoma and neuronal cells, (b) co-localization of GHsecreting adenoma and mature bone tissue, and (c) co-localization of $\mathrm{GH}$-secreting adenoma and nerve bundles.

In this study, immunoreactivity for nestin was observed in these three different phenotypes of $\mathrm{GH}$-secreting adenomas, not only in perivascular spaces of pituitary tumor vessels but also in parenchymal cells of the pituitary adenoma.
\end{abstract}

Conclusion: Various kinds of cells can differentiate from the stem cells in $\mathrm{GH}$-secreting adenomas, which may result in plurihormonality and pluripotentiality of adenomas.

Keywords: Acromegaly; GH-secreting adenoma; Plurihormonal; Multipotentiality; Pathological analysis; Nestin

\section{Introduction}

Plurihormonal adenomas of the pituitary are known to produce multiple hormones without any relation to lineage theory $[1,2]$. They may consist of one cell type secreting multiple hormones (monomorphous) or several cell types, each secreting one hormone (plurimorphous) $[3,4]$. In certain growth hormone $(\mathrm{GH})$-secreting adenomas, various combinations of pituitary hormones and tissue phenotypes, such as ganglion cells, mature bone and nerve bundles are observed.

This study was undertaken to determine whether multihormoneproducing pituitary adenoma cells originate from monoclonal or polyclonal cells. In addition, seven cases, which showed typical multipotentiality among 242 patients with GH-secreting adenomas, were extensively studied by immunohistochemical and electron microscopic analyses.

\section{Materials and Methods}

\section{Patient population}

Among 1711 surgically treated patients with pituitary adenoma, 242 (14\%) patients with GH-secreting adenoma underwent transsphenoidal surgery. A total of 229 cases with precise pathological analysis were included in this study. Of these patients, 101 were male and 128 were female. The mean age of patients was 48 years (range: 11-75 years).

The present study was conducted in accordance with the Declaration of Helsinki 1964. Informed consent was obtained from all patients.

\section{Neuroimaging}

The size and extent of the tumor were determined in all cases using magnetic resonance images (MRIs) obtained with a $1.5 \mathrm{~T}$ system (Magnetome; Siemens, Erlangen, Germany) and a 3.0 T MR unit (Signa HDx; General Electric, Fairfield, Connecticut, USA). T1- and
T2-weighted thick sagittal and coronal spin-echo MRIs were obtained as $2-3 \mathrm{~mm}$-thick slices. Additional T1-weighted axial, sagittal and coronal MRIs (500/15 ms) were obtained immediately after injection of $0.1 \mathrm{mmol} / \mathrm{kg}$ gadolinium-diethylenetriaminepenta-acetic acid (Schering, Berlin, Germany). Thin slices of Computerized Tomography (CT) were reconstructed in three-dimensions (3D). Positron Emission Tomography (PET)-CT studies were undertaken using a Discovery LS (General Electric, Fairfield, CN, USA) for all cases. All patients fasted before the procedure and received intravenous injections of $\left({ }^{11} \mathrm{C}\right)$ methionine (MET) (5.6 MBq $\times$ body weight (dose range, 225.7-558.3 $\mathrm{MBq})$. PET scans of 10-min durations were obtained starting at 20 min after injection. At $1 \mathrm{~h}$ after the MET injection, all patients received an intravenous injection of Fludeoxyglucose (FDG) (3.7 MBq $\times$ body weight (dose range, 155-269.5 MBq)). PET scans of 10 min durations were obtained starting at $60 \mathrm{~min}$ after injection. The MET-/FDG-PET procedure was performed in $3 \mathrm{D}$ mode, which provided a set of 35 planes with a section thickness of about $4.1 \mathrm{~mm}$. Uptake of FDG and MET during PET scanning was evaluated using a standardized uptake value $\max [5]$.

\section{Endocrinological examination}

The endocrine status of patients was evaluated before and after

${ }^{*}$ Corresponding author: Hidetoshi Ikeda, Research Institute for Pituitary Diseases, Southern Tohoku General Hospital, Koriyama, Fukushima 963-8563, Japan, Tel: +81-24-934-5322; Fax: +81-24-922-5320; E-mail: ikeda@nsg.med.tohoku.ac.jp

Received September 21, 2012; Accepted October 27, 2012; Published October 29, 2012

Citation: Ikeda H (2012) Plurihormonality and Pluripotentiality of $\mathrm{GH}$-Secreting Adenoma Based on Pathological Analysis of 242 patients with Acromegaly. J Metabolic Synd S2:003. doi:10.4172/2167-0943.S2-003

Copyright: (c) 2012 Ikeda $\mathrm{H}$. This is an open-access article distributed under the terms of the Creative Commons Attribution License, which permits unrestricted use, distribution, and reproduction in any medium, provided the original author and source are credited. 
Citation: Ikeda H (2012) Plurihormonality and Pluripotentiality of GH-Secreting Adenoma Based on Pathological Analysis of 242 patients with Acromegaly. J Metabolic Synd S2:003. doi:10.4172/2167-0943.S2-003

Page 2 of 6

surgery by measurement of serum levels of GH and Insulin-like Growth Factor-1 (IGF-1), prolactin, adrenocorticotropic hormone and cortisol, thyroid-stimulating hormone, free-T3 and free-T4, FollicleStimulating Hormone (FSH), Luteinizing Hormone (LH), estradiol and testosterone.

\section{Pathological examination}

Surgical specimens were fixed in 10\% neutral-buffered formalin and embedded in paraffin. Sections ( $3 \mu \mathrm{m}$ thick) were prepared and stained with Hematoxylin and Eosin (HE). Immunohistochemical staining was performed with the avidin-biotin complex method using the following antibodies: polyclonal anti-adrenocorticotropic hormone (Dako, Glostrup, Denmark), polyclonal anti-GH (Dako), polyclonal antiprolactin (Dako), monoclonal anti-thyroid-stimulating hormone- $\beta$ (Neo markers, Fremont, CA. USA), monoclonal anti-LH- $\beta$ (Cosmo Bio Co Ltd, Tokyo, Japan); monoclonal anti-FSH- $\beta$ (Cosmo Bio Co. Ltd); polyclonal anti- $\alpha$-subunit (Dako), monoclonal anti-keratin (Dako), monoclonal anti-S100 protein (Dako), monoclonal anti-glial fibrillary acidic protein (GFAP; Dako), monoclonal anti-neurofilament proteins (NFPs; 70, 168 and $200 \mathrm{kD}$ ), monoclonal anti-Ki-67 (Immunotech, Marseille, France), monoclonal anti-GH-releasing hormone (GRH; Dako), monoclonal anti- corticotropin-releasing hormone(CRH; Dako), monoclonal anti-microtubule-associated protein-2 (MAP-2; DAKO), monoclonal anti-pit1 (Santa Cruz Biotech, Santa Cruz, CA, USA), polyclonal anti-NeuroD1 (Chemicon, Temecula, CA, USA), and monoclonal anti-nestin (ImmQuest, Atlanta, GA, USA).

Electron microscopy used ultrathin slices stained with lead citrate and uranyl acetate.

\section{Strategy of clonal analysis}

DNA was extracted from tissue containing almost equal amounts of adenoma and neuronal elements. DNA extracted from peripheral blood and DNA samples known to be polyclonal were used for the polyclonal control as described elsewhere [6]. X-chromosome inactivation in females is a well-characterized event associated with a methylation change in $\mathrm{CpG}$ islands. One of the two X-chromosomes in each somatic cell of healthy females becomes inactivated randomly very early in embryonic development and the pattern of inactivation is permanent and consistent throughout cell division and neoplastic change. Normal female tissues are composed of a mosaic of cell types, which differs based on random maternally or paternally derived $\mathrm{X}$-chromosome inactivation. In contrast, tumor clones derived from a single cell should have the same X-chromosome inactivation pattern (non-random). Recently, a highly polymorphic trinucleotide CAG repeat in the X-linked human androgen receptor gene (HUMARA) has been used to distinguish between the two X-chromosome inactivation patterns and detect the clonality in various neoplastic diseases. Hha I, which does not digest methylated DNA, was used to digest the DNA before PCR to amplify the methylated allele. PCR primers were as follows: AR-F, 5'-FAM-AGGCACCCAGAGGCCGCGA-3' and AR-R, 3'-AACCCCTCTTGGTAGGAGTGG-5'. PCR products were analyzed using an ABI PRISM 310 GeneScan (POP-4 program). Peak areas obtained from the GeneScan Analysis Software were used to calculate a clonality ratio for both tumor and normal tissues: (lower allele/higher allele) digested/ (lower allele/higher allele) undigested. A clonality ratio below 0.4 , corresponding to an allele reduction of $60 \%$ or more, was considered to indicate tumor monoclonality.

To evaluate the multihormone-producing capacity of GH-secreting adenomas, immunohistochemical results of 123 cases of prolactin (PRL)-secreting adenoma [6] were used as a control.

\begin{tabular}{|l|l|l|}
\hline Immunophenotype of GH adenoma & No. of Cases & $(\%)$ \\
\hline GH+ PRL & 71 & 31 \\
\hline GH only & 29 & 13 \\
\hline ACTH+ GH+ PRL & 16 & 7 \\
\hline GH+ PRL+ TSH beta & 14 & 6 \\
\hline GH +PRL+ LH beta+ FSH beta & 12 & 5 \\
\hline GH+ PRL+ FSH beta & 12 & 5 \\
\hline ACTH+ GH+ PRL+ LH beta+ FSH beta & 11 & 5 \\
\hline ACTH+ GH+ PRL+ TSH beta+ LH beta+ FSH beta & 9 & 4 \\
\hline GH+ LH beta+ FSH beta & 7 & 3 \\
\hline ACTH+ GH+ PRL+ LH beta & 6 & 2.6 \\
\hline GH+ PRL+ LH beta & 6 & 2.6 \\
\hline GH+ PRL+ TSH beta+ LH beta+ FSH beta & 5 & 2.2 \\
\hline GH+ PRL+ TSH beta+ FSH beta & 5 & 2.2 \\
\hline GH+ FSH beta & 4 & 1.7 \\
\hline ACTH+ GH+ PRL+ FSH beta & 3 & 1.3 \\
\hline GH+ LH beta & 3 & 1.3 \\
\hline ACTH+GH & 3 & 1.3 \\
\hline GH+TSH beta & 3 & 1.3 \\
\hline ACTH+ GH+ PRL+ TSH beta+ FSH beta & 2 & 0.9 \\
\hline ACTH+ GH+ PRL+ TSH beta+ LHbeta & 2 & 0.9 \\
\hline GH+ PRL+ TSH beta+ LH beta & 2 & 0.9 \\
\hline ACTH+ GH+ FSH beta & 2 & 0.9 \\
\hline ACTH+ GH+ PRL+ TSH beta & 1 & 0.4 \\
\hline ACTH+ GH+ TSH beta+ LH beta & 2.8 & 0.4 \\
\hline Total & $100 \%$ \\
\hline Mean No. of hormones produced & 29 & \\
\hline & 2 & 1 \\
\hline
\end{tabular}

Table 1: Hormone production profiles in $\mathrm{GH}$-secreting adenomas detected by immunohistochemical staining.

\begin{tabular}{|l|l|l|}
\hline Immunophenotype & No. of Cases & $(\%)$ \\
\hline PRL only & 61 & 49 \\
\hline PRL+ aSU & 15 & 12 \\
\hline PRL+ GH & 15 & 12 \\
\hline PRL+ GH+ aSU & 8 & 7 \\
\hline PRL+ GH+ ACTH+ aSU & 7 & 6 \\
\hline PRL+ GH+ ACTH & 5 & 4 \\
\hline PRL+ ACTH & 4 & 3 \\
\hline PRL+ACTH+ aSU & 3 & 2 \\
\hline PRL+GH+ TSH beta & 2 & 2 \\
\hline PRL+ ACTH+ FSH beta+ aSU & 2 & 2 \\
\hline PRL+ GH+ FSH beta+ aSU & 1 & 1 \\
\hline Total & 123 & $100 \%$ \\
\hline Mean No. of hormones produced & 1.8 & \\
\hline
\end{tabular}

Table 2: Hormone production profiles in PRL-secreting adenomas detected by immunohistochemical staining.

\section{Results}

\section{Plurihormonality of GH-secreting adenomas (GHoma vs. PRLoma)}

The variety and proportion of hormone production in GHsecreting adenoma are shown in table 1 . There were 24 combinations of hormones with a mean of 2.8 hormones in GH-secreting adenoma. In contrast, the variety and proportion of hormone production in PRL-secreting adenoma are shown in table 2. There were 11 combinations of hormones with a mean of 1.8 hormones in PRL-secreting adenoma. GH-secreting adenoma showed a greater variety and number of hormones produced compared with those of PRL-secreting adenomas ( $\mathrm{p}<0.01$, Welch's $t$-test $)$. 


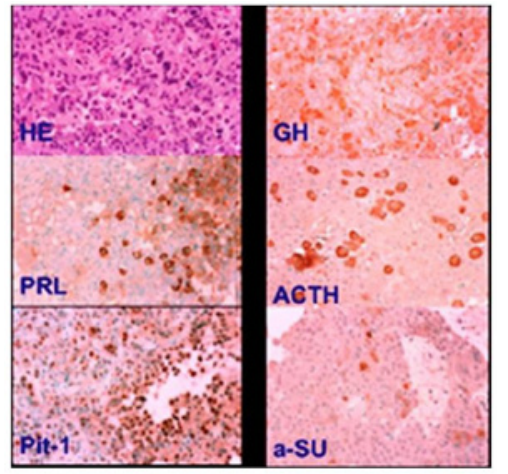

Figure 1: Pathological analysis of case 1, 44Y, Male.
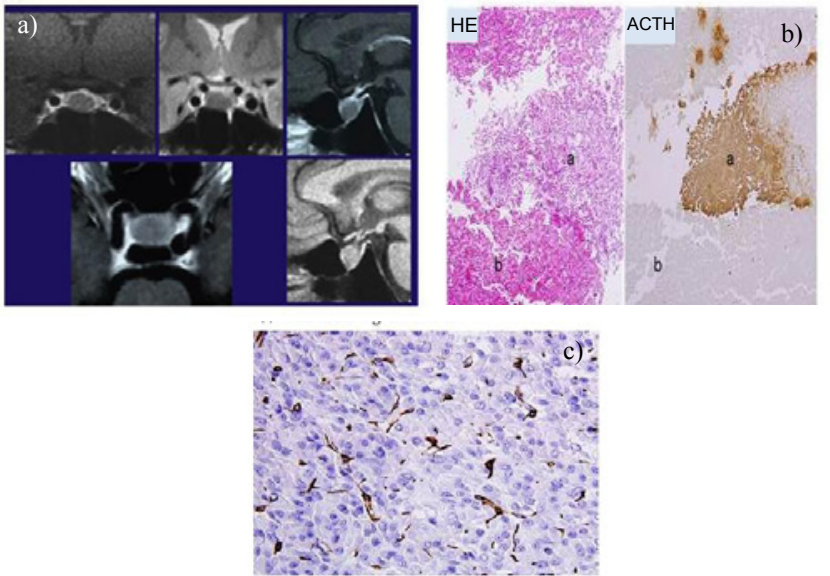

Figure 2: (a) MRI of case 2, (b) HE and immunohistochemical staining of the adenoma showing two different phenotypes (a and b) in case 2, (c) Nestin staining of case 2 .

\section{Adenoma with co-localized adrenocorticotropic (ACTH)- immunoreactive and GH-immunoreactive cells}

The number of cases with GH-secreting adenoma that simultaneously produced ACTH were 50 (21\%) out of 242 .

(Case 1): A 44-year-old male patient with acromegaly. Preoperative serum GH (30 ng/ml), IGF-1 (1380 ng/ml) and PRL (56.2 $\mathrm{ng} / \mathrm{ml}$ ) values were higher than normal values [7]. Other hormones, including ACTH $55 \mathrm{pg} / \mathrm{ml}$; cortisol $6.1 \mu \mathrm{g} / \mathrm{ml}$; TSH $1.6 \mu \mathrm{U} / \mathrm{ml}$; LH 1.55 $\mathrm{mIU} / \mathrm{ml}$ and FSH $4.04 \mathrm{mIU} / \mathrm{ml}$ were within normal levels (Figure 1). Immunohistochemical study revealed not only positivity for $\mathrm{GH}$, but also PRL, ACTH, and alpha-subunit, indicating that plurihormonal adenoma. ACTH-immunoreactive cells were distributed diffusely throughout GH-secreting adenoma.

\section{Adenoma with a small cell cluster of ACTH-immunoreactive cells differentiated mainly from GH-secreting adenomas (Two cases)}

(Case 2): A 35-year-old acromegalic male (Figure 2). High serum levels of GH (18.1 ng/ml) and (IGF-1) $(840 \mathrm{ng} / \mathrm{ml})$ were found. Other pituitary hormones, including PRL $6.32 \mathrm{ng} / \mathrm{ml}$; ACTH $22.9 \mathrm{pg} / \mathrm{ml}$; cortisol $10.4 \mu \mathrm{g} / \mathrm{ml}$; TSH $0.62 \mu \mathrm{IU} / \mathrm{ml}$; LH $1.34 \mu \mathrm{IU} / \mathrm{ml}$ and FSH 2.1 $\mu \mathrm{IU} / \mathrm{ml}$ were within normal limits. The tumor appeared as large as $13 \times 8 \times 8 \mathrm{~mm}$ on T1-weighted Gd-enhanced MRIs (Figure 2a). Operative findings revealed a glossy white homogeneously soft tumor.
Pathological examination revealed an adenoma with an apparently different histological type from that of existing GH-secreting adenoma. Two areas ('a' and 'b') showed a cell density that was quite different by HE staining (Figure $2 b$ ). In both areas ' $2 a$ ' and ' $2 b$ ', adenoma cells were immunoreactive for GH. The difference between the two areas was that adenoma cells were immunopositive and immunonegative for ACTH in areas ' $2 a$ ' and ' $2 b$ ', respectively (Figure $2 b$ ). Table 3 summarizes the above immunohistochemical results. Notably, cells positive for the stem cell marker nestin $[8,9]$ were observed diffusely in this adenoma tissue. Based on these data, some of the cells in this adenoma tissue had multipotentiality resulting in differentiation into not only GH-positive cells but also ACTH-positive cells (Figure 2c).

In this case, the stem cells were considered to be the precursor of $\mathrm{GH}$-secreting and ACTH-secreting adenomas.

(Case 3): A 69-year-old female with acromegaly diagnosed during examination of a head injury (Figure 3). High serum GH (53.7 ng/ $\mathrm{ml})$ and IGF-1 $(762 \mathrm{ng} / \mathrm{ml})$ values were revealed. Other pituitary hormones including ACTH $(49.1 \mathrm{pg} / \mathrm{ml})$, cortisol $(12.2 \mu \mathrm{g} / \mathrm{ml})$, TSH $(0.9 \mu \mathrm{IU} / \mathrm{ml})$, PRL $(2.6 \mathrm{ng} / \mathrm{ml}), \mathrm{LH}(19.8 \mathrm{mIU} / \mathrm{ml})$ and FSH $67.0(\mathrm{mIU} /$ $\mathrm{ml}$ ) were within normal limits. High urinary output of cortisol (329 $\mu \mathrm{g} /$ day) suggested ACTH-secreting adenoma. On MRIs, long roundshaped adenoma extending from the right lateral wing to the left lateral wing was observed (Figure 3a). Under the suspicion of double adenoma, super selective cavernous sinus sampling was carried out and revealed that the ACTH value from cavernous sinus blood was high compared with that in peripheral blood from a control vein. In addition, the ACTH value was higher in left-sided cavernous sinus blood. Adenoma specimens were surgically removed at every $4 \mathrm{~mm}$ interval (8 specimens) and subjected to pathological review (Figure 3c). Pathological examination revealed two phenotypes of the adenoma as follows: (1) Cells with eosinophilic cytoplasm and diffuse cell processes, which produced GH, PRL, and a-SU (Figure 3b), and (2) cells with pleomorphic nuclei and long cytoplasmic processes, which produced GH, ACTH, PRL, and a-SU (Figure 3d). Only specimen No. 8 showed positive immunoreactivity for ACTH; the rest of the specimens

\begin{tabular}{|l|l|l|l|l|l|l|}
\hline Adenoma cell location & GH & ACTH & PRL & Pit 1 & Neuro D1 & Ki-67 \\
\hline a & +++ & - & + & + & + & several \\
\hline b & ++ & +++ & ++ & +++ & +++ & A few \\
\hline
\end{tabular}

Table 3: Results of immunohistochemical staining for different locations ( $a$ and $b$ ) of adenoma cells.
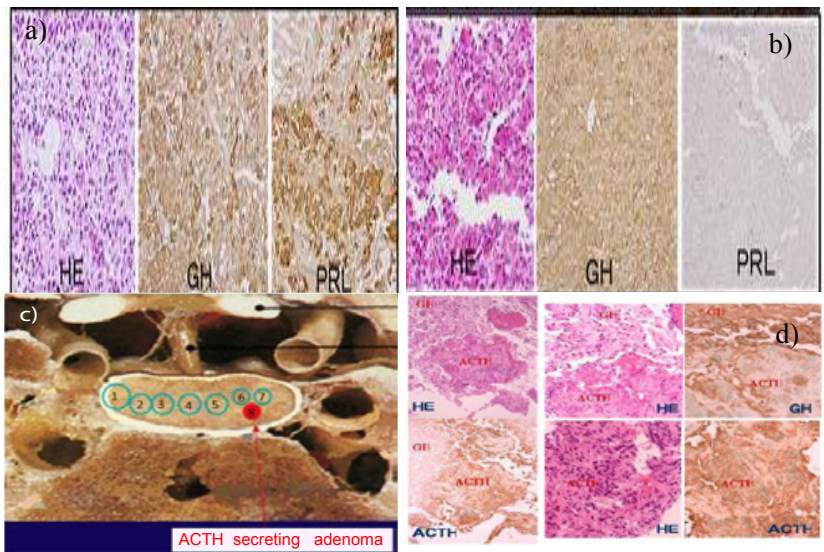

Figure 3: a) MRI of case 3, b) Histopathology of $\mathrm{GH}$-secreting adenoma, c) The location of adenoma specimens (No. 1-8), d) Histopathology of ACTHsecreting adenoma. 
(No. 1-7) were negative for ACTH. Specimen Nos. 1-7 showed immunoreactivity for Pit-1, but specimen No. 8 did not show a positive immunoreaction for pit-1 (Table 4). Nestin staining was not performed for this case. The majority of adenoma composed of $\mathrm{GH}$-and ACTHsecreting adenoma was localized in the left proximity of the tumor mass. Therefore, metaplastic processes were assumed to be obligatory in the progression of $\mathrm{GH}$-secreting adenoma to ACTH-secreting cells.

\section{Mixed tumors composed of adenoma and neuronal cells (two cases)}

(Case 4): A 55-year-old acromegalic woman presented with visual disturbance. Preoperative coronal and sagittal Gd-enhanced T1-weighted MRI showed heterogeneously Gd-enhanced suprasellar extending tumor compressing the optic chiasm (Figure 4a). High serum levels of GH (27.2 $\mathrm{ng} / \mathrm{ml})$ and IGF-1 (1060 ng/ml) were found. Other pituitary hormones were within normal limits: PRL $1.6 \mathrm{ng} / \mathrm{ml}$; TSH $0.543 \mathrm{mIU} / \mathrm{ml}$; LH 6.2 $\mathrm{mIU} / \mathrm{ml}$; FSH $26 \mathrm{mIU} / \mathrm{ml}$; ACTH, $59 \mathrm{pg} / \mathrm{ml}$ and cortisol $12.3 \mu \mathrm{g} / \mathrm{dl}$. The patient was treated by transsphenoidal operation.

Histological examination of the tumor specimen found adenoma cells (A) and a neuronal component (B) in varying proportions (Figure $4 \mathrm{~b}$ ). Immunohistochemical examination revealed both types of cells showed various amounts of $\mathrm{GH}$, prolactin, and alpha-subunit production. Cells in the neuronal component (B) were immunopositive for GRH, MAP2, NFP and synaptophysin (Figure 4c).

\begin{tabular}{|l|l|l|l|l|l|l|l|l|}
\hline Sample No. & ACTH & GH & PRL & TSH b & FSH b & LH b & a-SU & Pit 1 \\
\hline 1 & - & +++ & + & - & - & - & ++ & ++ \\
\hline 2 & - & +++ & + & - & - & - & ++ & ++ \\
\hline 3 & - & +++ & + & - & - & - & ++ & ++ \\
\hline 4 & - & +++ & + & - & - & - & ++ & ++ \\
\hline 5 & - & +++ & + & - & - & - & ++ & ++ \\
\hline 6 & - & +++ & + & - & - & - & ++ & ++ \\
\hline 7 & - & +++ & + & - & - & - & ++ & ++ \\
\hline 8 & ++ & +++ & + & - & - & - & +++ & - \\
\hline
\end{tabular}

Table 4: Results of immunohistochemical staining for adenoma tissues from various parts of the adenoma.
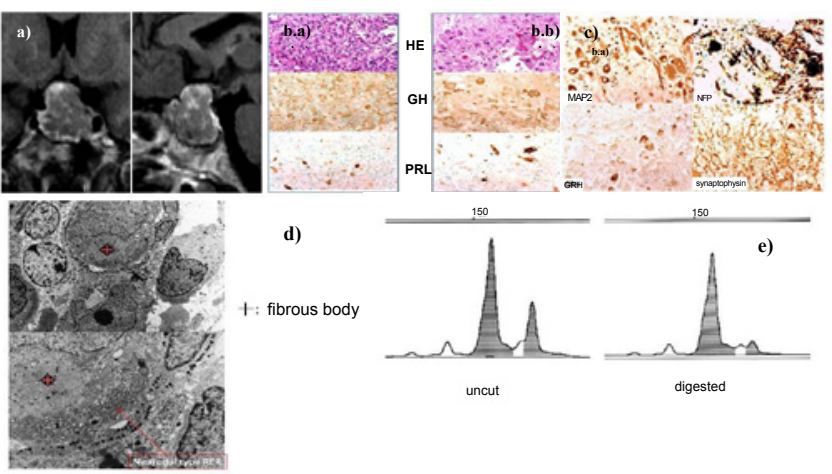

Figure 4: a) Coronal and sagittal views of case 4 in MRIs, b) Pathology of the two different phenotypes within the adenoma, (b. a) : Adenomatous portion; (b b): Ganglionic portion, c)Immunohistochemistry of the ganglionic portion, d) Electron microscopy of large transitional cells in the ganglionic portion.

(d. a) Electron micrograph of a large transitional cell containing an eccentric and crescent-shaped nucleus among fibrous body-like pituitary adenoma cells, but the RER of the neuronal type.

(d. b) Higher magnification of a) showing the RER of the neuronal type (Nissl body).

*: fibrous body.

+ fibrous body.

e) Clonal analysis: The HUMARA assay indicated a monoclonal pattern with a clonality ratio of 0.28 .

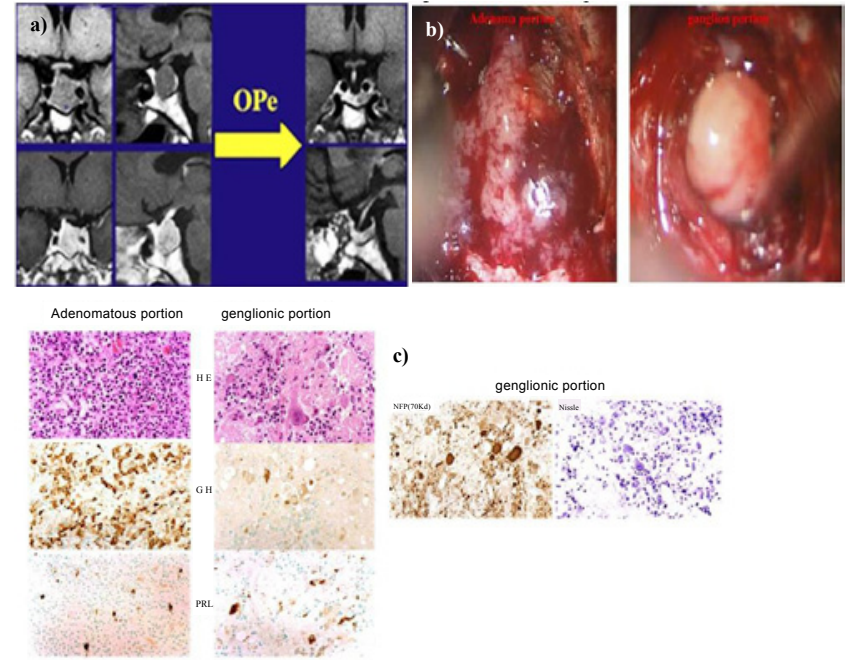

Figure 5: a) Pre- and post-operative MRI of case 5, b) Operative findings of the two different parts of the adenoma, c) Pathological findings of the two phenotypes (adenomatous and ganglionic regions) within adenoma.

Ultrastructural analysis showed the pituitary adenoma component exhibited features of sparsely granulated GH-secreting adenoma replete with fibrous bodies. Cells with Nissl substances also had fibrous bodies and sparse secretory granules (Figure $4 \mathrm{~d}$ ). Therefore, light and electron microscopy clearly revealed cells with a morphological transition between adenoma cells and neurons, and the tumor had a heterogeneous phenotype.

The HUMARA assay using DNA extracted from mixed adenoma and neuronal tissues indicated a monoclonal pattern with a clonality ratio of 0.238 (Figure 4e).

Because X-chromosome inactivation demonstrated monoclonality of these cells, the monoclonality of the coexisting pituitary adenoma and neuronal elements clearly showed that the two distinct components were not a chance association but rather the result of neuronal differentiation occurring within $\mathrm{GH}$-secreting adenoma.

In conclusion, transitional cells between adenoma and neuronal cells were revealed by electron microscopic study, and the HUMARA assay demonstrated that the tumor cells and neuronal tissue of the mixed lesion had originated from a single cell, although nestin staining was not performed for this case [7].

(Case 5): A 60-year-old acromegalic female patient complaining of headache and abducens palsy. The patient had a history of surgery for treating thyroid cancer, and thyradin medication was essential for her thyroid function, but she stopped taking thyroxin by self-judgment. Elevated levels of GH $(3.6 \mathrm{ng} / \mathrm{ml})$ and TSH $(33.2 \mu \mathrm{IU} / \mathrm{ml})$ were found, whereas free T4 showed a lower value than the normal range. Other hormones, such as PRL and IOGF-1, were within normal values. On MRIs, adenoma invading the cavernous sinus was observed (Figure 5a). Operative finding showed two different components of the tumor based on gross and histopathological observations (Figure 5b). Pathological examination revealed that cells in the adenomatous portion were $\mathrm{GH}$ and PRL-immunopositive, but other hormones were negative. Cells in the ganglionic portion were immunopositive for not only GH and PRL but also CRF, GRF, LHRH, MAP-2 and NFPs (70, 160 and 200 $\mathrm{kD}$ ) (Figure $5 \mathrm{c}$ ). Nestin staining was not performed for this case. Both adenomatous and ganglionic portions showed immunoreactivity for $\mathrm{GH}$ and PRL, and metaplastic processes were assumed to be obligatory in the progression of adenoma to ganglion cells $[8,9]$. 
Citation: Ikeda H (2012) Plurihormonality and Pluripotentiality of GH-Secreting Adenoma Based on Pathological Analysis of 242 patients with Acromegaly. J Metabolic Synd S2:003. doi:10.4172/2167-0943.S2-003

Page 5 of 6

\section{Co-localization of GH-secreting adenoma and mature bone tissue}

(Case 6): A 70-year-old female patient with acromegaly. High serum levels of GH $(9.67 \mathrm{ng} / \mathrm{ml})$ and IGF-1 $(640 \mathrm{ng} / \mathrm{ml})$ were found. Other pituitary hormones such as PRL (16.89 ng/ml) were within normal limits. Pre-operative examination by CT and MRI suggested bone or a calcified mass within the tumor (Figure 6a). Intraoperative findings showed a bone-like solid mass in the adenoma tissue. Immunohistochemical study revealed the adenoma was immunopositive for both GH and PRL. In addition, there was a fibrous mass containing a necrotic area intermingled with adenoma tissue. Adenoma cells were immunopositive for both GH and PRL, and cytokeratin staining showed a dotted pattern. Metaplastic bone formation was observed adjacent to the fibrous tissue (Figure 6b).

Only one similar case has been reported in the literature [10] Nestin-immunoreactive cells were observed diffusely or in cell clusters within GH-secreting adenoma (Figure 6c). Therefore, mature bone might have originated from these stem cells. In this case, stem cells
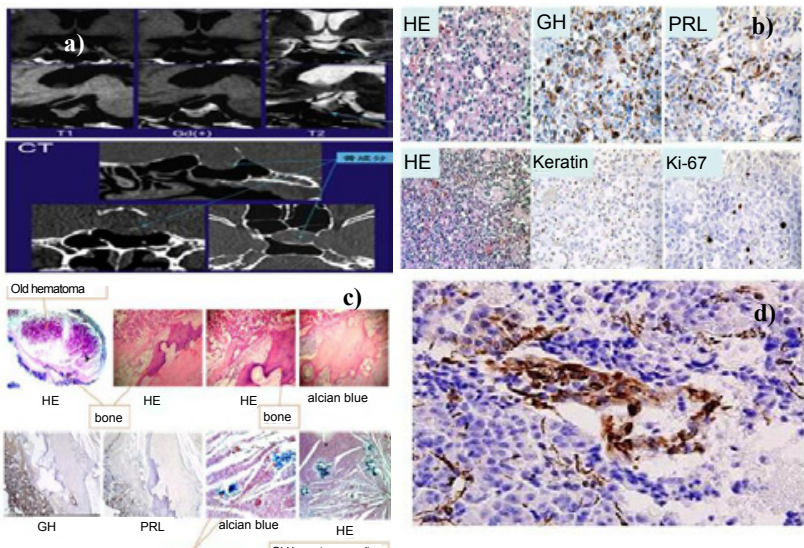

Figure 6: Nestin staining of case 6, a) MRL and 3D-CT of case 6, b) Pathologica findings of case $6, \mathrm{c}$ ) pathological finding of case 6 , d) Nestin staining in case 6 .

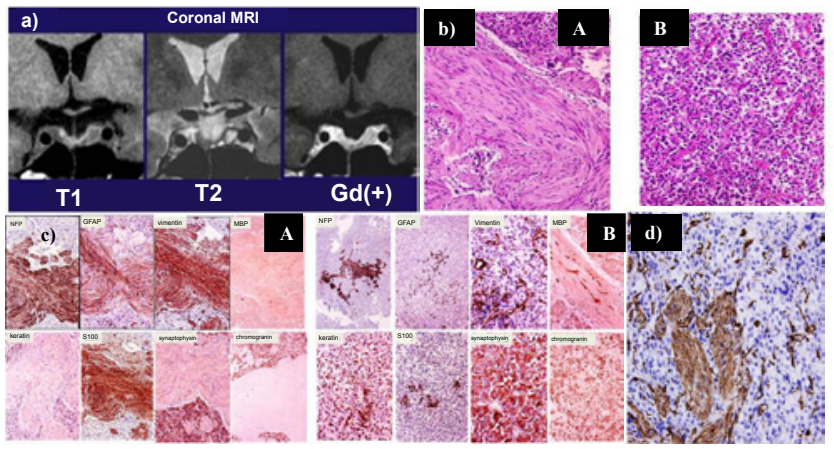

Figure 7: Nestin staining of case 7, a) MRI of case 7, b) $\mathrm{HE}$ staining of the nerve bundle-like portion ' $A$ ' and adenoma portion ' $B$ ', c) Immunohistochemical staining of 'A' and 'B' portions, d) Nestin staining in case 7. were also considered to be the precursor of GH-secreting adenoma and mature bone (Figure 6d).

\section{Co-localization of GH-secreting adenoma and nerve bundles}

(Case 7): A 47-year-old male diagnosed with an acromegalic feature and referred to our hospital for surgical treatment. The tumor appeared to be heterogeneous on both T1- and T2-weighted MRIs, and was heterogeneously enhanced by contrast medium (Figure 7a). High serum levels of GH $(11.7 \mathrm{ng} / \mathrm{ml})$ and IGF-1 $(726 \mathrm{ng} / \mathrm{ml})$ were found. Other pituitary hormones, such as PRL $6.8 \mathrm{ng} / \mathrm{ml}$; ACTH $39.6 \mathrm{pg} / \mathrm{ml}$ cortisol $14.5 \mu \mathrm{g} / \mathrm{dl}$; TSH $0.66 \mu \mathrm{IU} / \mathrm{ml}$; LH $1.3 \mu \mathrm{IU} / \mathrm{ml}$ and FSH $5.2 \mu \mathrm{IU} /$ $\mathrm{ml}$ were within normal levels.

The tumor was completely removed by the transsphenoidal approach after diagnosis of GH-secreting adenoma. The tumor was soft and slushy, grayish-white and measured $18 \times 12 \times 23 \mathrm{~mm}$.

Histology showed that the tumor was eosinophilic, slightly chromophobic, and a pituitary adenoma. It proliferated in a sinusoidal pattern intermingled with several foci of nerve bundle-like structures (Figure 7b). Adenoma cells were uniformly large and polyhedral with a round hyperchromatic nucleus. Immunohistochemical staining revealed that the majority of adenoma cells showed strong immunoreactivity for $\mathrm{GH}$, and several immunoreactive cells for PRL and TSH- $\beta$ were scattered within the adenoma. Immunohistochemistry showed negative results for the remaining adenohypophyseal hormones. Immunostaining for keratin revealed cytoplasmic accumulation of fibrous bodies in adenoma cells. All adenoma cells (A-part) showed immunoreactivity for pit-1, but not for Neuro D1. Adenoma cells also showed immunoreactivity for synaptophysin and chromogranin. Only scattered foliculosatellite cells (FSCs), which showed a star-like appearance in the adenoma, were immunopositive for GFAP, S-100 protein and vimentin (Figure $7 \mathrm{c}$ ). A nerve bundle-like structure (B-part) showed not only immunoreactivity for NFP and S-100 protein, but also for GFAP and vimentin. A dotted pattern of immunoreactivity for synaptophysin was observed in the nerve bundle-like structure. However, immunoreactive cells for chromogranin, pit-1, Neuro D1 and keratin were not observed in the nerve bundle-like structure (Table 5). Nestin-immunoreactive cells were found to be distributed in the adenoma tissue and along the nerve bundle fascicule (Figure $7 \mathrm{~d}$ ).

This case was special because of the co-existence of GH-secreting adenoma and an incomplete nerve bundle structure without ganglion cells [11]. There were two possibilities for the pathogenesis of this case. One theory was that somatotroph or FSCs acquired stem cell properties and, in certain circumstances, differentiated into various cell types. However, nestin staining revealed that nestin-positive cells were observed in both the adenoma component and along the periphery of the nerve bundle. Therefore, nestin-positive stem cells had transformed and differentiated into $\mathrm{GH}$-secreting cells and nerve bundles. In this case, stem cells were also considered to be the precursor of GHsecreting adenoma and the nerve bundle.

\section{Discussion}

The clonal analysis of case 4 (type 4) clearly demonstrated the

\begin{tabular}{|c|c|c|c|c|c|c|c|c|c|c|}
\hline & $\mathrm{GH}$ & PRL & TSH beta & Keratin & Pit-1 & Neuro D1 & MBP & NFP & GFAP & vimentin \\
\hline $\begin{array}{l}\text { Adenoma } \\
\text { cells }\end{array}$ & +++ & ++ & + & $\begin{array}{c}+++ \\
(\mathrm{FB}) \\
++ \\
(\mathrm{FSC})\end{array}$ & +++ & - & - & - & $\begin{array}{c}++ \\
(\mathrm{FSC})\end{array}$ & $\begin{array}{c}++ \\
(\mathrm{FSC})\end{array}$ \\
\hline Nerve bundle-like structure & - & - & - & - & - & - & + & +++ & ++ & +++ \\
\hline
\end{tabular}

Table 5: Distribution of immunoreactivities in both adenoma cells and the neuronal component. 
Citation: Ikeda H (2012) Plurihormonality and Pluripotentiality of GH-Secreting Adenoma Based on Pathological Analysis of 242 patients with Acromegaly. J Metabolic Synd S2:003. doi:10.4172/2167-0943.S2-003

Page 6 of 6

monoclonal origin of mixed GH-secreting adenoma and ganglioglioma. In light of this finding, six types of pathological conditions, as mentioned above, were assumed to result from pre-existing $\mathrm{GH}$ secreting adenoma cells undergoing metaplastic changes based on conventional immunohistochemical and electron microscopic studies.

Nestin is an established marker for stem/progenitor cells [12]. It was demonstrated that nestin-positive stem cells, which are different from endothelial cells within adenoma, were present in certain cases of GHsecreting adenomas. No nestin immunoreactivity has been found in the cells of various pituitary adenomas [13]. However, Weiss et al. [14] reported that immature pericytes are nestin positive and considered as multipotent progenitor cells of the pituitary gland. In addition, the differentiation of pericytes into cells of the neuronal lineage has been reported $[15,16]$. In light of these findings, it is not an exaggeration to presume that nestin-positive pituitary cells are stem cells that can differentiate into both pituitary and neuronal cells.

In this study, immunoreactivity for nestin was observed in cases 2 , 6 and 7, and not only in perivascular spaces of pituitary tumor vessels but also parenchymal cells of the pituitary adenoma. Nestin-positive stem cells might play a major role in producing a variety of pituitary hormones, as well as different kinds of tissues such as ganglion cells, mature bone and nerve bundles. GH-secreting adenoma showed both multihormone production and multipotentiality because of the presence of stem cells in GH-secreting adenoma. Involvement of nestin-positive stem cells in GH secreting adenoma is a problem to be solved in the future.

In conclusion, within a spectrum of GH-secreting adenoma, nestinpositive multipotent stem cells were confirmed to exist. Therefore, various kinds of cells can differentiate from the stem cells in $\mathrm{GH}$ secreting adenomas.

\section{References}

1. Scheithauer BW, Horvath E, Kovacs K, Laws ER Jr, Randall RV, et al. (1986) Plurihormonal pituitary adenomas. Semin Diagn Pathol 3: 69-82.

2. Ikeda H, Yoshimoto $\mathrm{T}$ (1988) Tumor growth and biological markers in pituitary adenomas. Neuropathology 18: 167-173.

3. Blevins LS Jr, Hall GS, Madoff DH, Laws ER Jr, Wand GS (1992) Case report:
Acromegaly and Cushing's disease in a patient with synchronous pituitary adenomas. Am J Med Sci 304: 294-297.

4. Vidal S, Syro L, Horvath E, Uribe H, Kovacs K (1999) Ultrastructural and immunoelectron microscopic study of three unusual plurihormonal pituitary adenomas. Ultrastruct Pathol 23: 141-148.

5. Ikeda H, Abe T, Watanabe K (2010) Usefulness of composite methioninepositron emission tomography/3.0-tesla magnetic resonance imaging to detect the localization and extent of early-stage Cushing adenoma. J Neurosurg 112 $750-755$.

6. Ma W, Ikeda H, Yoshimoto T (2002) Clinicopathologic study of 123 cases of prolactin-secreting pituitary adenomas with special reference to multihormone production and clonality of the adenoma. Cancer 95: 258-266.

7. Ikeda H, Ma W, Yoshimoto $\mathrm{T}$ (2003) Demonstration of monoclonality in a coexisting $\mathrm{GH}$-producing adenoma and neuronal tissue. Med Sci Monit 9: CS47-CS52.

8. Saeger W, Puchner MJ, Ludecke DK (1994) Combined sellar gangliocytoma and pituitary adenoma in acromegaly or Cushing's disease. A report of 3 cases. Virchows Arch 425: 93-99.

9. Kontogeorgos G, Mourouti G, Kyrodimou E, Liapi-Avgeri G, Parasi E (2006) Ganglion cell containing pituitary adenomas: signs of neuronal differentiation in adenoma cells. Acta Neuropathol 112: 21-28.

10. Roncaroli F, Fioravanti A, Marliani AF, Calbucci F (1999) Osseous metaplasia in a growth hormone-secreting pituitary adenoma. Clin Neuropathol 18: 205-207.

11. Ikeda H, Takayasu S (2008) A Growth Hormone-secreting adenoma with incomplete nerve bundle formation. Neuropathology 28: 317-321.

12. Toma JG, Akhavan M, Fernandes KJ, Barnabe-Heider F, Sadikot A, et al. (2001) Isolation of multipotent adult stem cells from the dermis of mammalian skin. Nat Cell Biol 3: 778-784.

13. Rotondo F, Kovacs K, Horvath E, Bell CD, Lloyd RV, et al. (2006) Immunoshistochemical expression of nestin in the non-tumorous hypophysis and in pituitary neoplasms. Acta Neuropathol 111: 272-277.

14. Weiss S, Siebzehnrubl FA, Kreutzer J, Blumcke I, Buslei R (2007) Evidence for a progenitor cell population in the human pituitary. Clin Neuropathol 28 309-318.

15. Dore-Duffy P, Katychev A, Wang X, Van Buren E (2006) CNS microvascular pericytes exhibit multipotential stem cell activity. J Cereb Blood Flow Metab 26: 613-624.

16. Messam CA, Hou J, Major EO (2000) Coexpression of nestin in neural and glia cells in the developing human CNS defined by a human-specific anti-nestin antibody. Exp Neurol 161: 585-596.
This article was originally published in a special issue, Pathophysiology and Treatment of Acromegaly handled by Editor(s). Dr. Hidetoshi Ikeda, Southern Tohoku General Hospital, Japan 